\title{
ANALYSIS OF POISONING CASES ADMITTED TO THE PEDIATRIC EMERGENCY DEPARTMENT: 5 YEARS OF CLINICAL EXPERIENCE
}

\section{Pediatrik Acil Servise Başvuran Zehirlenme Vakalarının Analizi: 5 Yıllık Klinik Deneyim}

\section{Oğuzhan ŞENSES ${ }^{1}$ (D), Serkan TURSUN ${ }^{1}$ (D), Ayșegül ALPCAN ${ }^{1}$ iD}

${ }^{1}$ Kırlkkale University, School of Medicine, Department of Pediatrics, KIRIKKALE, TÜRKIYYE

\begin{abstract}
Objective: Intoxication is one of the most acute causes of morbidity and mortality in childhood. Analyzing poisoning cases is considered noteworthy in terms of both adopting appropriate clinical practice approaches and taking relevant preventive measures.
\end{abstract}

Material and Methods: We reviewed a total of 674 pediatric intoxication cases admitted to our hospital over a 5-year period (2014-2019). We retrospectively extracted clinical data of all cases from the hospital information system and forensic records.

Results: Among all cases, we found the rate of intoxication to be $0.54 \%$ and the mean age at presentation to be $8.65 \pm 6.0$ years. While $51.5 \%$ of the cases were girls and $48.5 \%$ were boys. The most common cases were seen in children aged 1-5 years mostly boys with accidents and 15-17 years mostly girls with suicide causes. We detected that medical drugs ranked first place in poisoning with a rate of $39.5 \%$ and followed by intoxications due to carbon monoxide and chemical corrosive substances, respectively. Nervous system drugs (21.7\%) were more common in intoxication, while the most common drugs taken for suicide purposes were anti-depressants $(n=20 ; 16 \%)$. Symptomatic treatment was applied to the majority of the cases $(61.7 \%)$. The mean length of hospitalization was $1.23 \pm 1.22$ days and none of our patients were lost.

Conclusion: While drug intoxication is seen with a high frequency in all age groups, accidental intake is at the forefront at young ages, while suicide attempts are seen at a high rate in adolescent group and girls.

Keywords: Poisoning, children, suicide, emergency department, drugs

\section{ÖZ}

Amaç: Zehirlenmeler çocukluk çağının en akut morbidite ve mortalite nedenlerinden biridir. Zehirlenme vakalarının incelenmesi hem uygun klinik uygulama yaklaşımlarının benimsenmesi hem de ilgili önleyici tedbirlerin alınması açısından dikkate değer görülmektedir.

Gereç ve Yöntemler: $\mathrm{Bu}$ araştırmada 5 yıllık dönemde (2014-2019), 0-18 yaş arası toplam 674 çocuk zehirlenme olgusu incelendi. Tüm olguların klinik verileri hastane bilgi sistemi üzerinden geriye dönük olarak incelendi.

Bulgular: Tüm olgular arasında zehirlenme oranının $\% 0.54$ ve ortalama başvuru yaşının $8.65 \pm 6.0$ yıl olduğu görüldü. Olguların \%51.5'i kız, \%48.5'i erkekti. Zehirlenmelerin, bir-beş yaş arası erkeklerde çoğunlukla kaza sonucu, 15-17 yaş arası kızlarda ise intihar amaçlı olduğu saptanmıştır. En sık medikal ilaçlarla (\%39.5), ikinci sırada ise karbon monoksit ve kimyasal koroziv maddelerle zehirlenmeler görülmüştür.

Santral sinir sistemi ilaçları ile zehirlenmeler \%21.7 ile daha sık görülürken, intihar amaçlı en sık kullanılan ilaçlar olan antidepresanlar ile zehirlenme oranı \%16 idi. Olguların çoğuna (\%61.7) semptomatik tedavi uyguland. Hastanede kalış süresi ortalama $1.23 \pm 1.22$ gün olup hiçbir hastamız kaybedilmedi

Sonuç: Bütün yaş gruplarında ilaçla zehirlenme yüksek sıklıkta görülmekte, küçük yaşlarda kazara alım ön planda iken adölesan grubunda ve kız çocuklarında suisidal girișim niyeti yüksek oranda gözlenmiştir.

Anahtar Kelimeler: Zehirlenme, çocuklar, intihar, ilaçlar, acil servis 


\section{INTRODUCTION}

Intoxication is defined as harmful effects on the organism by any substances entering the body in any way $(1,2)$. Substances that disrupt the vital functions of that organism are called toxic substances (poison). Damage to the body from these substances is called intoxication (poisoning) (2). Unless proven otherwise, the medical staff need to suspect intoxication in all patients with multiple organ involvement whose cause is unknown. Poisoning can occur due to involuntary direct contact of toxic substances to the oral region, skin, and mucous membranes or inhalation, or voluntary intakes for suicide purposes $(2,3)$.

In Turkey, the National Toxicological Information Center (NTIC) was established in 1988 and actively continues to offer services. The studies report that childhood accidents, which rank second after traumas, are caused by intoxications $(4,5)$. The NTIC data reveal that drug poisoning is the most common in our country, and $50 \%$ of these cases are children (5). For this reason, comprehensive research is needed to investigate the poisoning cases by region to take the relevant precautions and determine the treatment and follow-up protocols in these unintentional poisonings.

In this retrospective, descriptive, cross-sectional study, we aimed to investigate the poisoning cases of childhood with their epidemiological and clinical characteristics in a university hospital set-up.

\section{MATERIALS AND METHODS}

\section{Ethical Considerations}

This retrospective, descriptive, cross-sectional study aimed to investigate the epidemiological, clinical, and laboratory findings of patients who presented to Kırıkkale University, School of Medicine, Pediatric Emergency Department with a complaint of intoxication between January 1, 2014 and November 1,2019. The study was approved by the local ethics committee (Kırıkkale University Ethics Committee of NonInterventional Research, date: 11/27/2019; issue number: 2019.11.19).

\section{Patients}

We studied the data of patients who applied to Kırıkkale University, School of Medicine, Pediatric Emergency Department between January 1, 2014- November 1, 2019 with a complaint or suspicion of poisoning (The retrospective analysis period was started from date of 2014 due to automation system activation of hospital.)

Poisoning diagnosis of the patients were done according to clinical history, symptoms and simple laboratory toxicology analysis (urine analysis and blood carbon monoxide level evaluation). For intoxications with medications, it was considered that the maximum daily therapeutic dose was exceeded.

The following cases were excluded: the patient without a diagnosis or suspicion of intoxication, patient with missing information, chronic poisoning, food poisoning and inert foreign body ingestions.

\section{Data Collection}

We collected the demographic data such as age, gender, time of occurrence, time of admission, the time interval between the intake of the active substance, the complaint during the admission to the pediatric emergency department, the cause of poisoning and the route of intake. In the study, we considered eight-hour time intervals between the time of the event and the time of admission to the hospital.

We grouped drugs causing intoxication in the patients and examined their frequencies among the cases. We noted the symptoms by the drug groups and sought the symptom types and frequencies by these drugs. We surveyed the distribution of cases by seasons, months, and years. Then, we checked whether drug intake was by accident or for self-destructive purposes and recorded the distribution of these two groups by age and gender. 
We obtained the records related to consulting NTIC and retrospectively reviewed the treatments that the patients received and the use of the antidote. We noted the vital signs of the patients at the time of first admission, urgent treatment requirements, and the need for hospitalization or intensive care. Statistical Analysis

We utilized SPSS 20.0 (IBM SPSS, Chicago, USA) for statistical analyses in the study. We displayed descriptive statistics as variability and frequency. We run the Kolmogorov-Smirnov and Shapiro-Wilk tests to check the normality of the data. In continuous variables, we analyzed parametric ones with the Student's T-test and non-parametric ones with the Mann-Whitney U test. In multiple group comparisons, we used One-Way ANOVA for parametric data while preferring the Kruskal-Wallis test (with post-hoc tests) for nonparametric data. We compared categorical data using the Chi-square or Fisher's exact test where applicable. To evaluate the risk of suicidal intoxication according to gender, we applied binary logistic regression analysis. Finally, we considered a p-value less than 0.05 statistically significant.

\section{RESULTS}

The study was conducted with 775 children that applied to the pediatric emergency department due to acute poisoning among 123,478 total patient admissions. The admission due to poisoning was $0.62 \%$ (775/123478). Full clinical data were available for only 674 children.

While $51.5 \%(n=347)$ of the patients were girls, $48.5 \%$ $(n=327)$ were boys. We found that the cases were most prevalent in the age range of 1-5 years $(n=261)$ and 10$14(n=159)$ years. Among these cases, 1-5 years of age was dominated by boys $(n=261)$, and the girls were mostly between $10-14$ years $(n=159)$.

We found that the highest number of admissions were in $2017(27.4 \%)$, October (16\%), and autumn (28.5\%), respectively. It was noteworthy that the cases $(47.2 \%)$ were most admitted to the emergency department between 08.00 and 16.00 .

The most common way of presenting to the hospital was through the 112 Emergency Line (48.7\%) and with the help of a family member (46\%), respectively. In addition, the patients most frequently (42.3\%) presented to the emergency department 30-60 minutes after the event. We determined that the patients were most often exposed to the agents orally $(68 \%)$, followed by inhalation with $28.9 \%$.

Analysis of the Cases by Gender, Age, and Etiology

The mean age of those presenting due to suicide was $14.39 \pm 1.05$ years, while that of those poisoned by accident was $6.68 \pm 5.54$ years. We found that the cases significantly took the agent for suicide $(\mathrm{p}<0.001)$ in the spring $(29.5 \%)$ and winter $(26.8 \%)$ and admitted to the emergency department through the 112 Emergency Line $(\mathrm{p}<0.001)$. When compared by age, children aged 15-17 years significantly took the agent for suicide $(\mathrm{p}<0.001)$, and the patients poisoned themselves more by accident in all other ages. Among self-poisoning cases, 61.7\% were girls, which was significantly higher than boys $(p=0.006)$. Moreover, it was noteworthy that the risk of suicide was higher in girls [OR: 1.69 (1.16-2.47, \%95 CI)]. Regarding the etiology of the agents, we concluded that medical drugs took first place with $39.5 \%$ (Table 1).

\section{Analysis of the Cases by Drug Agent}

We noted that age groups 0-1 year and 1-5 years mostly used analgesic, antipyretic, and anti-inflammatory drugs, and those aged 10-14 years and 15-17 years were poisoned due to the use of multiple drugs. Regarding non-drug agents, corrosive substance intake was leading in the group aged 0-1 year, followed by carbon monoxide exposure in other age groups. We found that intoxication by accidents occurred among the patients significantly due to non-drug agents $(\mathrm{p}<0.001)$, and those taking agents for suicide used mostly drugs $(\mathrm{p}<0.001)$. The nervous system drugs and analgesic- 
anti-inflammatory drugs ranked first place, considering the drug-poisoned cases (Table 2).

\section{Analysis of Cases by Symptoms, Laboratory Findings}

More than half of the cases $(66.9 \%)$ consulted the NTIC, and $61.3 \%$ of the patients had at least one or more complaints at the time of application; the most common complaint was nausea-vomiting (33.4\%) (Table 3). We discovered that $65 \%$ of non-drug intoxications and $55.6 \%$ of drug intoxications were symptomatic $(\mathrm{p}=0.015)$.

Table 1: Etiological distribution of poisoning cases

\begin{tabular}{lc}
\hline Agent & $\mathbf{n}(\%)$ \\
\hline Medical drugs & $266(39.5)$ \\
Carbon monoxide poisoning & $120(17.8)$ \\
Corrosive Substance & $113(16.8)$ \\
Chemical gas & $61(9.1)$ \\
Food & $21(3.1)$ \\
Raticide & $20(3.0)$ \\
Thinner & $15(2.2)$ \\
Ethanol & $13(1.9)$ \\
Pesticides & $7(1.0)$ \\
Plants & $3(0.4)$ \\
Mercury & $2(0.3)$ \\
Mushroom & $1(0.1)$ \\
Insect bite & $1(0.1)$ \\
Other & $33(4.7)$ \\
\hline
\end{tabular}

Among the cases subjected to toxic substance analysis, we found carbon monoxide (61.4\%) and paracetamol (15.1\%) poisoning to be the most frequent.
When the cases were divided into two groups as accident and suicide international normalized ratio (INR) values $(\mathrm{p}=0.004)$ were significantly higher in those who took the factor by accident; on the other hand, activated partial thromboplastin time values were found to be significantly higher in those with the agent intent on suicide $(p=0.036)$. When the cases were grouped according to the agent they took, it was observed that prothrombin time elevation $(\mathrm{p}=0.047)$ was significantly more common in cases poisoned by non-drug agents.

Analysis of the Cases by Treatment and Clinical Followup

We noticed that decontamination was applied to $36.3 \%$ of the cases, while $67.7 \%$ of these cases were taken to gastric lavage and activated charcoal. The specific antidotes were administered as following intoxicated drugs: 20 paracetamol, two benzodiazepines, two betablockers, and one iron preparations.

Among the patients, $63.8 \%$ required hospitalization. Two hundred and twenty patient were discharged after admission to the short stay emergency service. Fifty-five patients were observed in intensive care unit and 24 patients who needed intubation were referred to tertiary center due to absence of pediatric intensive care unit. The patients who needed intubation were referred to the appropriate centers. There were no exitus from intensive care observation.

Concerning the mean length of stay of the cases by agent and reason for intake, we reached the finding that the patients who took the agent for suicide and who used a drug as the agent had significantly longer hospitalization periods $(\mathrm{p}<0.001)$. 
Table 2: Types of Poisoning in Drug-Poisoned Cases by Agent

\begin{tabular}{|c|c|c|}
\hline \multirow[t]{2}{*}{ Drug Group } & \multicolumn{2}{|c|}{ Poisoning Type } \\
\hline & Accident (n) & Suicide (n) \\
\hline SSRI $^{*}$ & 6 & 17 \\
\hline $\mathrm{TCA}^{* *}$ & 8 & 3 \\
\hline Antipsychotics & 5 & 6 \\
\hline Anti-Anxiety Drugs & 3 & 0 \\
\hline Psychostimulant & 2 & 1 \\
\hline Antiepileptics & 1 & 3 \\
\hline Paracetamol & 19 & 11 \\
\hline Salicylate & 19 & 4 \\
\hline Ibuprofen & 2 & 3 \\
\hline Antacids & 5 & 2 \\
\hline Antispasmodics & 6 & 0 \\
\hline Constipation drugs & 2 & 0 \\
\hline \multicolumn{3}{|l|}{ Antihypertensives } \\
\hline Beta-Blocker & 5 & 0 \\
\hline Calcium Channel Blocker & 4 & 1 \\
\hline Angiotensin-Converting & 4 & 0 \\
\hline \multicolumn{3}{|l|}{ Enzyme Inhibitors } \\
\hline Diuretic & 1 & 0 \\
\hline \multicolumn{3}{|l|}{ Other Drugs } \\
\hline Combination Cold & 7 & 9 \\
\hline \multicolumn{3}{|l|}{ Medicines } \\
\hline Hormone Preparations & 13 & 1 \\
\hline Antibiotics & 4 & 5 \\
\hline Vitamins & 5 & 2 \\
\hline Oral Antidiabetics & 2 & 1 \\
\hline Iron Preparations & 0 & 2 \\
\hline Antihistamines & 1 & 1 \\
\hline Anticoagulant Drugs & 2 & 0 \\
\hline Dyslipidemia Drugs & 1 & 0 \\
\hline
\end{tabular}

*Selective serotonin reuptake inhibitors, ** Tricyclic antidepressants
Table 3: Complaints of the Cases During Admission

\begin{tabular}{|c|c|}
\hline Complaint & $\mathrm{n} / \%$ \\
\hline Nausea-Vomiting & $225 / 33.4$ \\
\hline Headache & $171 / 25.4$ \\
\hline Dizziness & $134 / 19.9$ \\
\hline Fatigue & $113 / 16.8$ \\
\hline Altered Consciousness & $83 / 12.3$ \\
\hline Abdominal Pain & $73 / 10.8$ \\
\hline Cough & $71 / 10.5$ \\
\hline Palpitation & $61 / 9.1$ \\
\hline Swallowing Difficulty & $56 / 8.3$ \\
\hline Walking Impairment & $44 / 6.5$ \\
\hline Vision Impairment & $32 / 4.7$ \\
\hline Respiratory Difficulty & $25 / 3.7$ \\
\hline Wheezing & $12 / 1.7$ \\
\hline Attack & $11 / 1.6$ \\
\hline
\end{tabular}

\section{DISCUSSION}

The important findings we observed in our study were as follows: Most of the poisoning agents were exposed by mouth, the risk of suicide was higher in girls than boys, and the most prominent symptoms were nausea and vomiting at the time of emergency admission.

Poisoning is one of the important preventable and treatable causes of morbidity and mortality in childhood $(6,7)$. The frequency of poisoning cases among emergency department admissions varies from country to country and even within the same country due to social, cultural, and geographical differences (8-10). The higher incidence of intoxication cases in our study can be explained by the more frequent communication between the physicians and the NTIC in recent years and the advancement in the educational attainment levels of the families. The findings of our study in terms of age and drug agent are compatible with the literature $(11,12)$. The desire to be independent starting at the age 
of 2-3 years and the increased mobility of children between the ages of 1-5 years may be underlying causes of a high frequency of intoxication cases in these age groups. Moreover, the insufficient attention of families should not be ignored in such cases.

We found that 2017 was the year when cases presented to the emergency department the most. This result may be due to the high number of poisoning cases caused by chlorine gas accident in our city in 2017 (13). Besides, we concluded the cases were most frequent in autumn and discovered mixed results on this issue in the literature $(14,15)$. In studies conducted by including all agents and regions where people mostly utilize stoves for heating, carbon monoxide poisoning was an expected finding to be observed frequently in autumn and winter seasons, which may explain the seasonal difference in our study.

In poisoning cases, on-time arrival at emergency departments is critical for the success of treatment $(16,17)$. In our study, we found out that $62.5 \%$ of the cases presented to the emergency department within the first hour of the event. In addition, we realized that the cases taking the agent for self-destructive purposes were brought more frequently by an ambulance. This finding may have emerged because the relatives of these cases called the 112 Emergency Line to obtain the first intervention immediately. We also noted that the cases presented to the emergency department mostly between 08:00 and 16:00, and this finding bears some differences compared to the literature (18). Again, the reason for this may be that these children may have been more active and that caregivers might have been busy with housework during these hours.

Many studies reported that the intake route of the agents was mainly through the mouth $(19,20)$. Similarly, our study revealed that poisoning by oral agent intake took the first place. In studies conducted on the etiology of intoxication cases, drugs were generally in the first place among the leading agents $(21,22)$. In our study, we also found the drug intake to rank first place among the cases.
Yet, the order of non-drug agents in poisoning varies in the literature (22). Among our cases, $17.8 \%$ were poisoned by carbon monoxide gas, and this rate was higher than the literature (18). This elevated rate may be due to the frequent use of stoves in our region and the lack of adequate precautions to prevent poisoning. The fact that our hospital is often preferred for the treatment and follow-up of carbon monoxide poisoning in our city may have caused this rate to be higher.

The mortality rate of poisoning cases ranged from $0.1 \%$ to $3.9 \%$ in previous studies. Yet, none of the patients in our study was lost, which may have been related to the transfer of our patients, needing tertiary level pediatric intensive care, to other centers (19-25). Oner et al. found the need for pediatric intensive care need to be $4.4 \%$, while Kondolot et al. determined it to be $5.7 \%(26,27)$. We discovered this rate to be $8.2 \%$, which was thought to be related to the relatively higher rate of multi-drug and carbon monoxide intoxication in our study. The participating cases, especially those poisoned by drugs and agents for suicide, stayed longer in the hospital. It may be due to the concern of the patients that the agents taken for suicide would lead to more severe complications.

The limitations of our study originate from the retrospective design and the single-center data. In addition, we could not obtain information from the archive records, such as electrocardiogram results of the cases, where the event occurred, who accompanied with the case, who owned the agents, and the educational attainments of the patients' relatives. Some cases were excluded from the study due to insufficient data, so the number of patients included in the study was found to be lower than the expected number of poisonings in the same period. In addition, since our study is a singlecenter study, it causes an underestimation of the actual frequency of poisonings in our region. Also due to absence of pediatric intensive care unit in our hospital, data of referred patients were not determined. In 
addition to retrospective studies in terms of poisoning, further prospective and multicenter studies are needed. We observed that pediatric emergency department should be alerted about intoxication with usually used preparations as antibiotics and anti-flu drugs. In addition, it should be kept in mind that more investigations and advanced care may be required, especially in drug and suicidal poisonings. Our results suggest the necessity to take relevant measures to reduce the suicide cases of female adolescents and raise awareness among the parents of 1-5-year-old children about poisoning.

Conflict of Interest: The authors declare that they have no conflict of interest.

Author contributions: OS planned and designed this study. He has collected the data and performed the literature survey. ST planned and designed this study. He has researched the literature survey, has performed the statistical analysis and interpretation of the results. He wrote the article. AA planned and designed this study. She has collected the data, performed the literature survey. She performed the latest intellectual review of the manuscript and submitted to the journal. Support and Acknowledgements: There is no funding source.

Ethical Committee Approval: Kırıkkale University Ethics Committee of Non-interventional Research; date: 11/27/2019, issue number: 2019.11.19.

\section{REFERENCES}

1. Mintegi S, Azkunaga B, Prego J, Qureshi N, Dalziel $\mathrm{SR}$, Arana-Arri E et al. International epidemiological differences in acute poisonings in pediatric emergency departments. Pediatr Emerg Care. 2019;35(1):50-7.

2. Gummin DD, Mowry JB, Spyker DA, Brooks DE, Osterthaler KM, Banner W.2017 Annual Report of the American Association of Poison Control Centers'
National Poison Data System (NPDS): 35th Annual Report. Clin Toxicol (Phila). 2018;56(12):1213-5.

3. Sahin S, Carman KB, Dinleyici EC. Acute poisoning in children; data of a pediatric emergency unit. Iran J Pediatr. 2011;21(4):479-84.

4. Özcan N, İkincioğulları D. Ulusal Zehir Danışma Merkezi 2008 Yılı Çalışma Raporu Özeti. Türk Hij ve Deney Biyol Derg. 2009;66(ER-3):29-58.

5. Yağcı R, Aydoğdu S, Taneli B. Çocukluk çağı kazalarının acil popülasyondaki yeri. XXXVI Milli Pediatri Kongresi Özet Kitab1, Antalya Türk Pediatri Kurumu Yayınlar1. 1994:41.

6. Dayasiri MBKC, Jayamanne SF, Jayasinghe CY. Patterns and outcome of acute poisoning among children in rural Sri Lanka. BMC Pediatr. 2018;18(1):274.

7. Yılmaz R, Albayrak SE, Gül A. Çocuk yoğun bakim ünitesinde tedavi edilen zehirlenme vakalarinin retrospektif değerlendirmesi. Pediatr Pract Res. 2017;5(2):19-26.

8. Sümer V, Güler E, Karanfil R, Dalkıran T, Gürsoy $\mathrm{H}$, Garipardıç $\mathrm{M}$ et al. Çocuk acil servisine başvuran zehirlenme olgularının geriye dönük olarak değerlendirilmesi. Turk Arch Pediatr. 2011;46(3):234-40.

9. Eliaçık K, Kanık A, Karanfil Ö, Rastgel H, Metecan A, Oyman $\mathrm{G}$ et al. An evaluation of the admissions to a tertiary hospital pediatric emergency department with intoxication. Smyrna T1p Dergisi. 2012;2:41-4.

10. Aygin D, Açıl H. Çocuk acil ünitesine başvuran 018 yaş arasi zehirlenme olgularinin incelenmesi. Ş.E.E.A.H. Tıp Bülteni. 2014;48(1):27-33.

11. Yalaki Z, Taşar MA, Yalçın N, Bilge YD. Çocukluk ve gençlik dönemindeki özkıyım girişimlerinin değerlendirilmesi. Ege T1p Derg. 2011;50(2):125-8.

12. Dinleyici M, Kıral E, Yazar AS, Şahin S İlaç intoksikasyonu ile başvuran ergenlerde özkıyım ilişkili risk faktörlerin değerlendirilmesi. Osmangazi Tıp Dergisi. 2019:41(2):166-72. 
13. Tursun S, Alpcan A, Kandur Y. Clinical spectrum of acute chlorine poisoning in children. Türkiye Çocuk Hast Derg. 2021:1-4. Doi:10.12956/tchd.835355.

14. Tunçok Y, Kalyoncu K. TC Sağlık Bakanlığı birinci basamağa yönelik zehirlenmeler tanı ve tedavi rehberleri. Ankara, SB, RSHMB, Hifzıssıhha Mektebi Müdürlüğü, Bakanlık Yayınları (No:712), 2007.

15. Akbay-Öntürk Y, Uçar B. Eskişehir bölgesinde çocukluk çağı zehirlenmelerinin retrospektif değerlendirilmesi. Çocuk Sağlığı ve Hastalıkları Dergisi. 2003;46:103-13.

16. Benson BE, Hoppu K, Troutman WG, Bedry R, Erdman A, Höjer J et al. Position paper update: gastric lavage for gastrointestinal decontamination. Clin Toxicol (Phila). 2013;51(3):140-6.

17. Soyucen E, Aktan Y, Saral A, Akgün N, Numanoğlu AU et al. Sakarya bölgesinde çocukluk çağ 1 zehirlenmelerinin geriye dönük değerlendirilmesi. Çocuk Sağlığı ve Hastalıkları Dergisi. 2006;49(4):301-6.

18. Deniz T, Kandiş H, Saygun M, Büyükkoçak Ü, Ülger H, Karakuş A. Kırıkkale Üniversitesi Tıp Fakültesi acil servisine başvuran zehirlenme olgularinin analizi. Duzce Medical Journal. 2009;11(2):15-20.

19. Yorulmaz A, Akbulut H, Yahya İ, Aktaş R, Emiroğlu HH, Peru H. Çocuk acil servisine zehirlenme nedeni ile başvuran olguların geriye dönük olarak değerlendirilmesi. J Pediatr Emerg Intensive Care Med. 2017;10(4):96-103.

20. Yılmaz HL. Çocuklarda karbon monoksit zehirlenmesi. Türkiye Klinikleri J Pediatr Sci 2006;2(5):67-71.

21. Seydaoglu G, Satar S, Alparslan N. Frequency and mortality risk factors of acute adult poisoning in Adana, Turkey, 1997-2002. Mt Sinai J Med. 2005;72(6):393-401.
22. Arapoğlu M, Keskin C, Telhan L, Erdem E, Palanduz A. Şişli Etfal Hastanesi 1. Çocuk Kliniği'ne başvuran zehirlenme olgularının değerlendirilmesi. Şişli Etfal Tıp Bülteni. 2005;39(4):41-5.

23. Karcioğlu Ö, Demirel Y, Esener Z, Ozer I, Salama M. Acil serviste ilaç ile zehirlenmeler: bir yıllık olgu serisi. Türkiye Acil Tıp Dergisi. 2002;2(2):26-33.

24. Biçer S, Sezer S, Çetindağ F, Kesikminare M, Tombulca N, Aydogan $\mathrm{G}$ et al. Çocuk acil kliniği 2005 y1l akut zehirlenme olgularının değerlendirilmesi. Marmara Medical Journal. 2015;20(1):12-20.

25. Akkas M, Coskun F, Ulu N, Sivri B. An epidemiological evaluation of 1098 acute poisoning cases from Turkey. Veterinary and Human Toxicology. 2004;46(4):213-5.

26. Öner N, İnan M, Vatansever Ü, Turan C, Çeltik C, Küçükuğurluoğlu et al. Trakya bölgesinde çocuklarda görülen zehirlenmeler. Türk Ped Arş. 2004;39(1):25-30.

27. Kondolot M, Akyıldız B, Görözen F, Kutoğlu S, Patıroğlu T. Çocuk acil servisine getirilen zehirlenme olgularının değerlendirilmesi. Çocuk Sağ ve Hastalıkları Dergisi. 2009;52(2):68-74. 